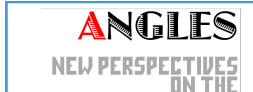
ANELOPHONE WORLD

\section{Angles}

New Perspectives on the Anglophone World

9| 2019

Reinventing the Sea

\title{
Teaching Global History and Geography Using the Indian Ocean as a Unit of Analysis
}

\section{Ingrid Sankey}

\section{Q OpenEdition}

1 Journals

\section{Electronic version}

URL: https://journals.openedition.org/angles/810

DOI: 10.4000/angles.810

ISSN: 2274-2042

\section{Publisher}

Société des Anglicistes de l'Enseignement Supérieur

\section{Electronic reference}

Ingrid Sankey, "Teaching Global History and Geography Using the Indian Ocean as a Unit of Analysis", Angles [Online], 9 | 2019, Online since 01 November 2019, connection on 06 June 2022. URL: http:// journals.openedition.org/angles/810 ; DOI: https://doi.org/10.4000/angles.810

This text was automatically generated on 6 June 2022.

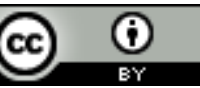

Angles est mise à disposition selon les termes de la Licence Creative Commons Attribution 4.0 International. 


\title{
Teaching Global History and Geography Using the Indian Ocean as a Unit of Analysis
}

\author{
Ingrid Sankey
}

1 The units of analysis historians and geographers use enable them to identify key questions about the past and the present which, in turn, determine which stories are told and, eventually, what patterns emerge. This is why units of analysis can be regarded as framing tools that help scholars identify patterns at different scales in their analysis of global processes. By focusing on seas and ocean basins, one can bring out the processes of interaction that have connected peoples living in the various regions around a sea and ocean basin up to the present day.

2 To illustrate this recent development in the fields of History and Geography, one may recall the pioneering work of French historian Fernand Braudel who was the first to use the large-scale unit of analysis of the Mediterranean Sea as a framework for his study of the reign of Philip II of Spain, originally published in 1949. In a paper published in the Journal of Modern History in 1972, Braudel wrote:

I contemplated the Mediterranean, tête à tête, for years on end and my vision of History took its definitive form without my being entirely aware of it, partly as a direct intellectual response to a spectacle - the Mediterranean - which no traditional historical account seemed capable of encompassing. (Braudel 1972: 453-4)

Nowadays, as Global History is emerging as a dominant paradigm and develops new and innovative approaches in various fields of the Humanities, large scale studies have emerged in History, a field previously reluctant to such vast units of analysis. As Global Geography is now being taught in French lycées (high schools), the Indian Ocean framework, like Braudel's Mediterranean Sea decades ago, can be used to explain the early development of global trade networks and regional cross-cultural interactions in what is commonly referred to as the old World, as opposed to the New World "discovered" by Christopher Columbus in 1492 . 
The finest example of such large scale oceanic studies is that of French historian Philippe Beaujard who published a rather exhaustive analysis of the history of the Indian Ocean, recently translated into English (Beaujard 2012, 2019). In this vast study, he displays a broad-spectrum analysis of a very large area that stretches from the Eurasian Silk Roads network to the island of Madagascar, and from the Himalayas to the African Swahili coast and the archipelagoes of South East Asia. The topics addressed range from the economics and politics of the region through the analysis of maritime and land-based trade networks, to an anthropological study of the ethnic diversity found across this vast unit of analysis, from Antiquity to the arrival of Europeans in the Indian Ocean in the $15^{\text {th }}$ century.

This paper will deal with this recent and unprecedented use of the Indian Ocean as a global framework for historical and geographic analysis in teaching and research fields, showing why discussing in class the Indian Ocean world as a zone of dynamic interaction between peoples makes more pedagogical, historical and geographic sense in a globalized world than using traditionally delineated national or continental units.

One must acknowledge the limitations of the use of such a broad unit of analysis, however, and the potential teleological bias that prompts historians and teachers to try integrating the human past into a comprehensive big picture that emphasises the shared experiences of all humans, sometimes at the expense of a more traditional historiography focusing on the idea that the human past is marked by important differences between peoples across space and time.

7 This is why the major issue for Global History and Geography is to reconcile the idea of an increasing integration at the global scale with that of an increasing difference at the local and regional scales, and to construct and teach a global historical and geographic narrative of the past and of our contemporary world that may help students understand the growing complexities and challenges of Globalization.

In an introduction to the history of the Indian Ocean World in a teacher's resource website in 2007, Erik Gilbert stated that, even though world historians do not seem to agree on a common definition of World History, the majority concede that "if world history has an opposite, something it strives not to be, it is national history" (Gilbert 2006-7: 6). Like most modern fields of study, History and Geography as we know them today were born at the end at the $19^{\text {th }}$ century, in an era of dynamic state building. The preferred unit of analysis that emerged to frame historians and geographers' narratives of the world's past and present was, and to some extent still is, the national scale. It is easy to acknowledge the ideological background that has led most countries around the world to build national histories to back emerging national identities, at a time when another political unit, the Imperial one, was crumbling almost everywhere. Today, the United Nations hosts 193 member states (South Sudan is the latest addition in 2011). All are national political entities.

9 Nevertheless, over the past decades, History and Geography, like many other fields of study, have had to adapt to a paradigm shift that has enlarged the scope of their narratives from a national to a global scale. This new paradigm is what defines most of our contemporary representations of the world: globalization. One could discuss the validity or reality of such a broad and ill-defined concept and its consequences over various fields of studies, including the Humanities, but this goes beyond the scope of this paper. 
As world history emerged as a global alternative to the national narrative, it soon became clear that a global perspective also had to include a transdisciplinary approach in its analysis to provide a truly global perspective on history and geography. The fields of History and Geography have thus become more connected than ever before. Broader units of analysis have been added to the nation state, such as civilizations, area studies, continents, language groups... All in an attempt to transcend the limits of the nationstate. But as Erik Gilbert recalls, "the more we employ these units of analysis, the more they start to seem like nation-states warmed over" (Gilbert 2006-7: 6). Some of these broader units are geographic ones: natural spaces or ecosystems such as deserts, grasslands, mountains or oceans. These harsh environments, which may look like barriers limiting human contacts, have come to be regarded as "zones of interactions" that have served as meeting places between peoples of different backgrounds (Gilbert 2006-7: 6).

11 The Indian Ocean is one such place and it provides History and Geography teachers with examples of trade, travel, migration, imperial conquest and religious and cultural interaction in almost every period that reach far beyond the limits of national state borders. This approach aims at enabling students to analyse events and phenomena with a broadened perspective and a less restricted focus, introducing the complexities of writing historical and geographical narratives that manage to articulate the global and the local in a coherent and comprehensive analysis of past and present events.

Seas and oceans, by their size and contact with multiple and diverse areas, look like the perfect historical and geographic frame to display exchanges of all kinds and scales, an aspect sometimes overlooked by classical history.

Figure 1. The Indian Ocean floor, by NatGeo dated 1967

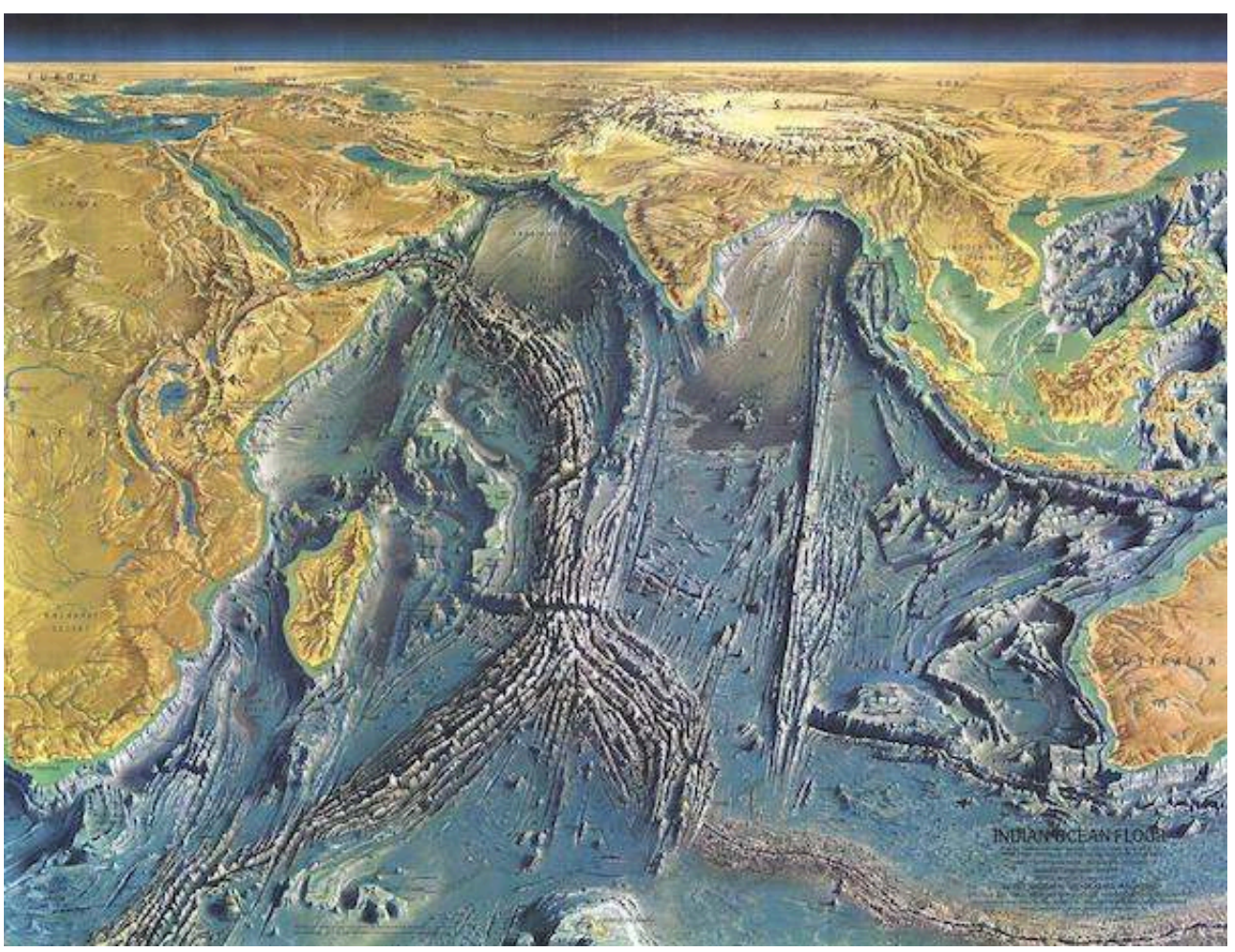

Source: https://imgur.com/elhUdNv 

facilitated contacts between societies that had access to diverse resources. The richness and complexity of these cross-regional connections set the pattern for the globespanning interconnections we know today as globalization.

Jerry Bentley has argued that since the Second World War, historians have focused more closely on large-scale processes that have deeply influenced both the experiences of individual societies and the development of the world as a whole. These processes include mass migration, campaigns of imperial expansion, cross-cultural trade, biological exchanges, transfers of technology and cultural exchanges that have left a mark on the world's past. Therefore, "adequate study of these processes requires historians to recognize analytical categories much larger than national communities" (Bentley 1999:1). foundation for Immanuel Wallerstein's world-system theory (Wallerstein 1974) and that of large-scale ecological zones has developed our understanding of processes of biological diffusions and their widespread and long-lasting consequences, such as the Great plague in Eurasia or the so-called "Columbian exchange" (Crosby 1972) between the old World and the New World.

As History unfolds on different levels and scales such as local, regional, continental, hemispheric, oceanic, global, and so on, processes of integration and differentiation maintain tension at all levels.

In the lack of stable nailed-down categories capable of supporting historical and geographical analysis at all times and places, sea and ocean basins offer particularly useful alternatives to earlier constructs because of their capacity to bring focus to so many large-scale processes of social and economic integration. (Bentley 1999: 9)

Nevertheless, seas and oceanic frameworks would not serve well as the absolute or definitive categories of historical analysis because their contours and characteristics have changed dramatically over time with shifting relationships between bodies of water and masses of land (Wallerstein 1974: 1).

Despite their advantages, such categories no doubt mirror an era of globalization and may represent a significant bias as they have the potential to serve at legitimising altogether an ideology of globalism that endorses or promotes the contemporary capitalist style of present-day globalization. In order to prevent such teleological biases, large-scale processes and cross-cultural interactions that have long been important ingredients in the development of human societies must be subject to analysis and critique. This is why the study of sea and ocean basins must probe the connections and dynamics fuelling processes of integration in individual maritime regions without losing sight either of the local experiences or global interactions that sometimes conditioned the experiences of the regions themselves (Wallerstein 1974: 9).

Connections made by water routes have helped integrate distant peoples through trade, contact and cultural influences for thousands of years. It also led to the spreading of religious traditions across distant regions as goods and commodities were not travelling alone along these ancient trade networks. Furthermore, contacts made through water-based as well as land-based trade also caused peoples to become more aware of cultural differences and sharpen distinction between diverse societies. 
20 In a manual of World History published in 2013, Candice Goucher and Linda Walton recall that World/global history looks for global patterns that emerge from the world's vast collection of historical narratives and for significant connections across both time and space. In doing so, it aims to attenuate the tensions between the dynamics of continued global integration, mostly through international trade, at the global scale and the acceleration of proliferating differences at the local scale. These two opposing trends are still important features of our contemporary globalization. Therefore, it is fair to acknowledge that, even if historians create narratives of the past from records of individual and collective experiences, they interpret the past in response to questions shaped by the world they live in (Goucher 2013: 5).

21 French historian Fernand Braudel is usually credited with being one of the first to acknowledge the sea as a unit of analysis in his study of The Mediterranean and the Mediterranean World in the Age of Philip II, published in 1949. In those days, historians were beginning to probe the impact of global processes that had caused two major world-scale conflicts. As the title suggests, Braudel identifies the "Mediterranean Sea" as the geographic physical background of his analysis and the "Mediterranean World" understood and described as the cultural space and manmade territory created, delineated and organized by successive waves of peoples who settled around the coastline surrounding what geographers call this "body of water" that is the Mediterranean Sea over past millennia (Braudel 1949, 1972).

Braudel's work consists of three volumes, each dealing with different time scales. The first volume deals with geological times and focuses on the physical geography of the Mediterranean Sea and its surrounding lands, such as the climate, the landscapes, the natural resources and raw materials available to the various peoples dwelling on its shores. It seeks to analyse Mediterranean societies in their geographic context and assess the impact of the environment on the history of the region and on the creation of a somewhat unified Mediterranean space. He acknowledges that geography is not enough, however, and that "the Mediterranean had no unity but that created by the movements of men, the relationships they imply, and the routes they follow" (Braudel 1972: 276).

23 Following this methodology, the second volume deals with societies at large and focuses on the long social time needed for the development of social processes that contributed to the creation or evolution of specific cultures and civilisations. That is the time that is needed to create social structures, to develop social processes, cultural identities and long-lasting political structures - a time that measures the impact of cross-cultural interactions or the creation of hybrid societies. These processes usually develop and unfold over several generations.

24 The third volume deals with what previous historians regarded as real History, eventful time, the time of historical individual events understood in the span of a human lifetime.

Nowadays, world regions far from the Mediterranean can be referred to as "Mediterranean Seas," such as the Caribbean or the South China Sea. These interconnected regions share common features that define the "Braudelian" Mediterranean, thus shaping single space units forming what can be referred to as unique maritime worlds. An example that shows the vitality of Braudel's legacy in France is the publication of a book by François Gipouloux on "The Asian 
Mediterranean, port-cities and trade networks in China, Japan and Southeast Asia from the $16^{\text {th }}$ to the $21^{\text {st }}$ century" (Gipouloux 2009).

This leads us to another, much larger, maritime unit of analysis, that of the Indian Ocean, which raises the question of the unity of such a vast, diverse but densely interconnected, maritime region.

In his book on the history of the Indian Ocean first published in 2008, Michael Pearson raises the following question: is there something which we call the Indian Ocean and which can be studied, analysed, treated as a coherent object? For Pearson,

The Indian Ocean is not only older, it also has a fundamentally different history. The Mediterranean has always been dominated by people from its littoral; the North Atlantic is the creation of people from one of its coasts; the Pacific arguably was created by Europeans, but in the Indian Ocean there is a long history of contact and distant voyages done by peoples from its coasts, and then a brief hiatus, maybe 150 years, when Westerners controlled things. (Pearson 2010:5)

He also recalls that Andre Gunder Frank in ReOrient, first published in 1998, has claimed that the Indian Ocean area, extending to the South China Sea, has been central to global history in all the millennia up to about 1800 , and is now re-emerging as a major area of exchange and interactions in the Old world. By contrast, European dominance in the world covers at most 200 years out of a total of perhaps six millennia (Gunder Frank 2010: 4).

The first comprehensive study of the Indian Ocean as a unit of historical analysis following Braudel's footsteps was the K.N. Chaudhuri's Trade and Civilization in the Indian Ocean: an Economic History from the Rise of Islam to 1750, published in 1985.

There was a firm impression in the minds of contemporaries, sensed also by historians later, that the ocean had its own unity, a distinct sphere of influence. Means of travel, movements of people, economic exchange, climate and historical forces created elements of cohesion. Religion, social systems, and cultural traditions on the other hand, provided the contrasts (Gipouloux 2009).

As Pearson recalls, Chaudhuri comes to the conclusion that, for certain kinds of analysts, the Indian Ocean is a single unit of space, and that for others it is not and must be broken-up into smaller entities (Pearson 2010: 5). Some scholars advocate that, in spite of the great variety of landscapes and ecosystems (from rainforests to deserts, and continents to islands), the lands bordering the Indian Ocean had a lot in common, from the garland of harbours along the coasts where maritime trade met land-routes to the common kinds of ships used, such as the elegant dhows which used to roam across these oceanic territories long before Sindbad, the famous sailor of the Arabian Nights.

On the contrary, other scholars such as Frank Broeze suggest that the term 'Indian Ocean' is inappropriate and refers to

a string of closely related regional systems stretching from East Asia around the continent and across the Indian Ocean to East Africa, to which sea space a new generic name such as "the Asian Seas" might well be given. (Broeze 1989: 3-21)

What makes the Indian Ocean unique is that it was the first real ocean that humans could cross rather than just clinging to the shorelines, using the regular pattern of Monsoon winds. Erik Gilbert adds that the Indian Ocean is more like a giant version of the Mediterranean, the archetype of the manageable, human-scale body of water, and quite unlike the Atlantic and Pacific Oceans which were, until fairly recently,

insurmountable barriers, crossed only by accident or out of desperation [...] if the

Mediterranean may take the prize for earliest long-distance trade, as there seems 
to have been a maritime trade in Obsidian as early as $6000 \mathrm{BCE}$, it lacks both the size and ecological variety of the Indian Ocean. (Gilbert 2006-7: 6-7) one may acknowledge, as Gilbert suggests, that what makes the Indian Ocean interesting is its lack of unity. It is large enough to connect different cultures and environments. Unlike the Mediterranean, which runs east-west, the Indian Ocean includes environments as varied as tropical East Africa and its grassland, wooded, mountainous and desert hinterland, the deserts that border the Red Sea and the Persian Gulf, the hot and wet areas around Southern India and the tropical rainforests covering both mainland and island Southeast Asia (Gilbert 2006-7: 8). Revealingly, Fernand Braudel's analysis of the Mediterranean Sea has sometimes been criticised for the author's clear focus on its Northern shores, rarely providing facts about the Southern shore of Mare Nostrum.

her element that makes the Indian Ocean such a interesting unit of analysis is that it is, together with the Mediterranean Sea, one of two major and interconnected bodies of water of what is commonly referred to as "the Old World" as opposed to the New Atlantic and Pacific Worlds. The Indian Ocean is the only body of water of such geographic scale that witnessed the early development of regular and extensive trade networks long before the arrival of Europeans. It allows teachers using this unit of analysis to adopt a different historical approach, one less influenced by $19^{\text {th }}$-century Eurocentric perceptions of the world. To illustrate this point, teachers can use several maps drawn before the arrival of European conquerors in the Indian Ocean, such as AlIdrissi's world map designed in 1154 (Figure 2), or the Kangnido map designed in Korea in 1402 (Figure 3). These maps provide visions of the world at different periods of time that are not exclusively or specifically centred on the Mediterranean Sea or the European continent. 
Figure 2. A map of the world by Al-Idrisi (1154) in The Book of Roger, Norman king of Sicily, showing the Mediterranean Sea and the Indian Ocean

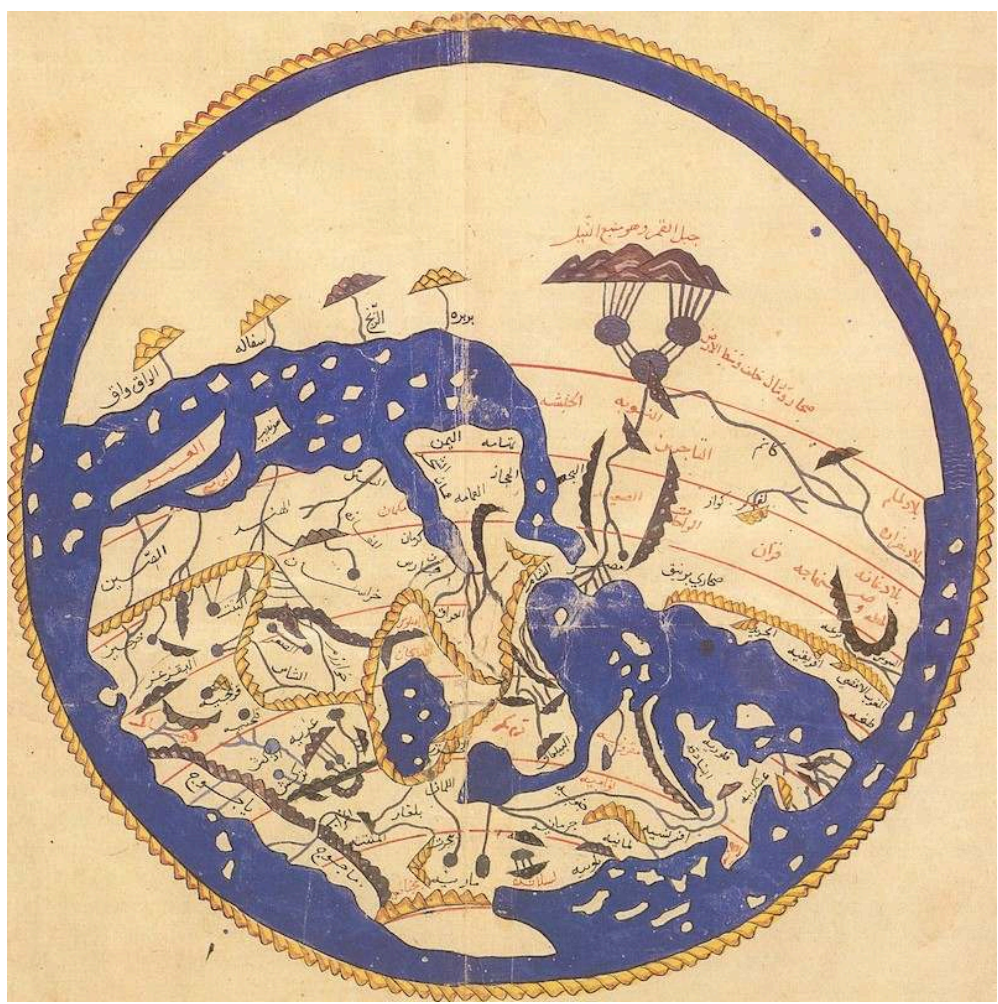

The map is centred on the Arabian Peninsula at the crossroads between the two bodies of water. Note the southern orientation of the map.

Source: https://commons.wikimedia.org/wiki/File:1154_world_map_by_Moroccan_cartographer_alIdrisi_for_king_Roger_of_Sicily.jpg 
Figure 3. The Kangnido Map (1402)

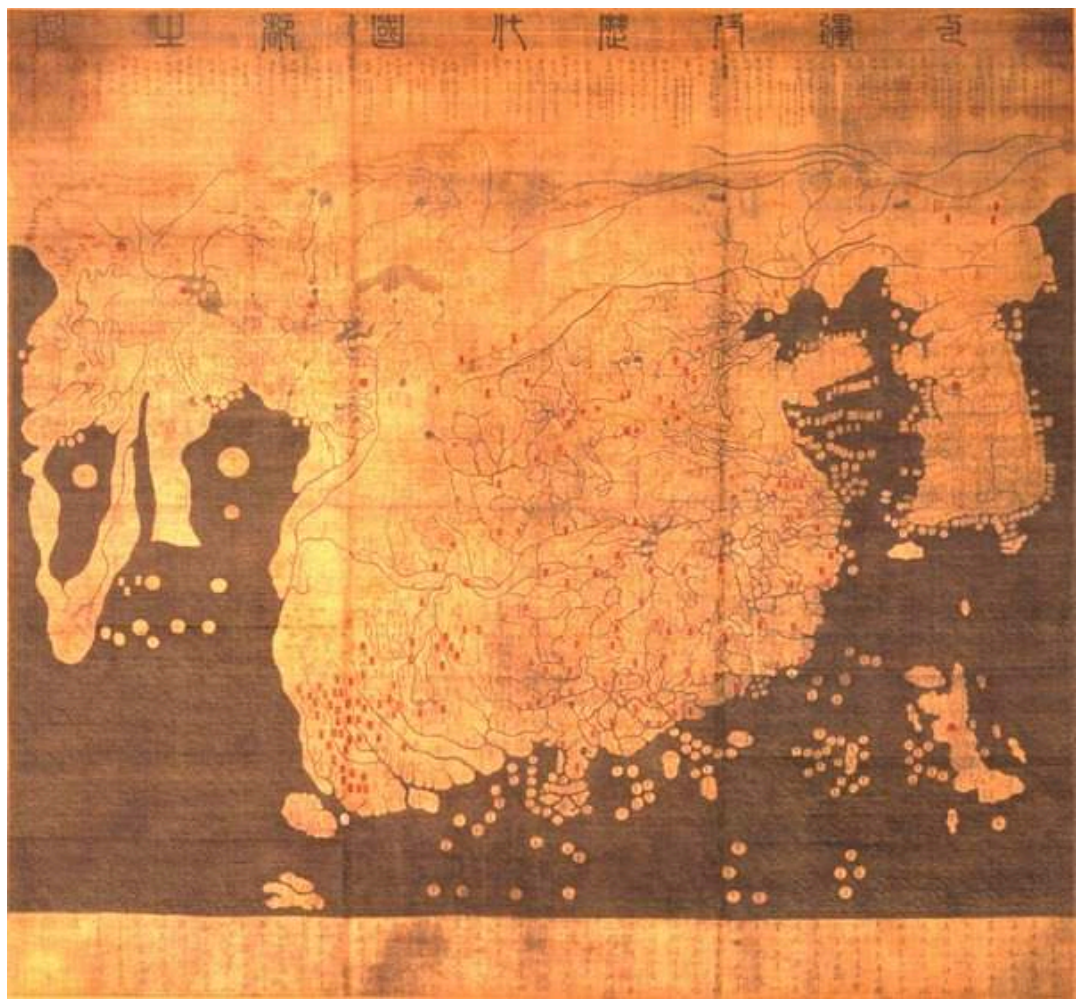

A Chinese perspective on the Indian Ocean.

Source: https://upload.wikimedia.org/wikipedia/commons/7/75/KangnidoMap.jpg

Varied units of analysis may include the study of trade networks and areas of strategic importance for communications around the Indian Ocean at different periods of time and in different sub-regional areas such as the Persian Gulf, the Red, Arabian and South China Seas, the straits of Hormuz, Bab El-Mandeb or Malacca in Southeast Asia, the Swahili shores along the East African coast, the Mozambique Channel or the Bay of Bengal.

Depending on the period studied, topics can range from the ancient maritime Spice Routes network, or the Medieval Swahili coastal and urban network of trading citystates to the Portuguese Estado da India in the $16^{\text {th }}$ century, or the British colonial Empire and its shift to the East after the loss of large parts of its American Atlantic empire in the $18^{\text {th }}$ century.

Students may be asked to evaluate the significance and impact of the development of global trade networks in the history of the Old World that included the interconnected system made of the Mediterranean Sea and the Indian Ocean, as opposed to the New Atlantic and Pacific Worlds "discovered" after 1492. They may also identify and describe zones of interaction and areas of hybridity and creolization and assess the impact of trade on local cultures and societies with respect to arts, religious beliefs and syncretisms, food and diets, languages, science and techniques. Other ideas include the evaluation of the consequences of trade on political, economic, social and cultural structures of various societies in the rimlands surrounding the ocean and on their natural environments. To further their analysis, students may present their network in space and time. They may use different maps with different scales, identify core and peripheral areas and describe the organisation of the trade networks included in their 
units of analysis. They may be asked to draw their own annotated maps and produce their own timelines. networks, using a systemic approach. Students may identify and describe big port cities around the Indian Ocean such as those where the trans-continental Silk Roads met the maritime Spice Routes network to form huge cosmopolitan hubs and crossroad areas such as the trans-Saharan caravan trade network or the Frankincense routes from the Arabian peninsula and the shores of the Oman Sultanate.

Figure 4. A map of the Indian Ocean

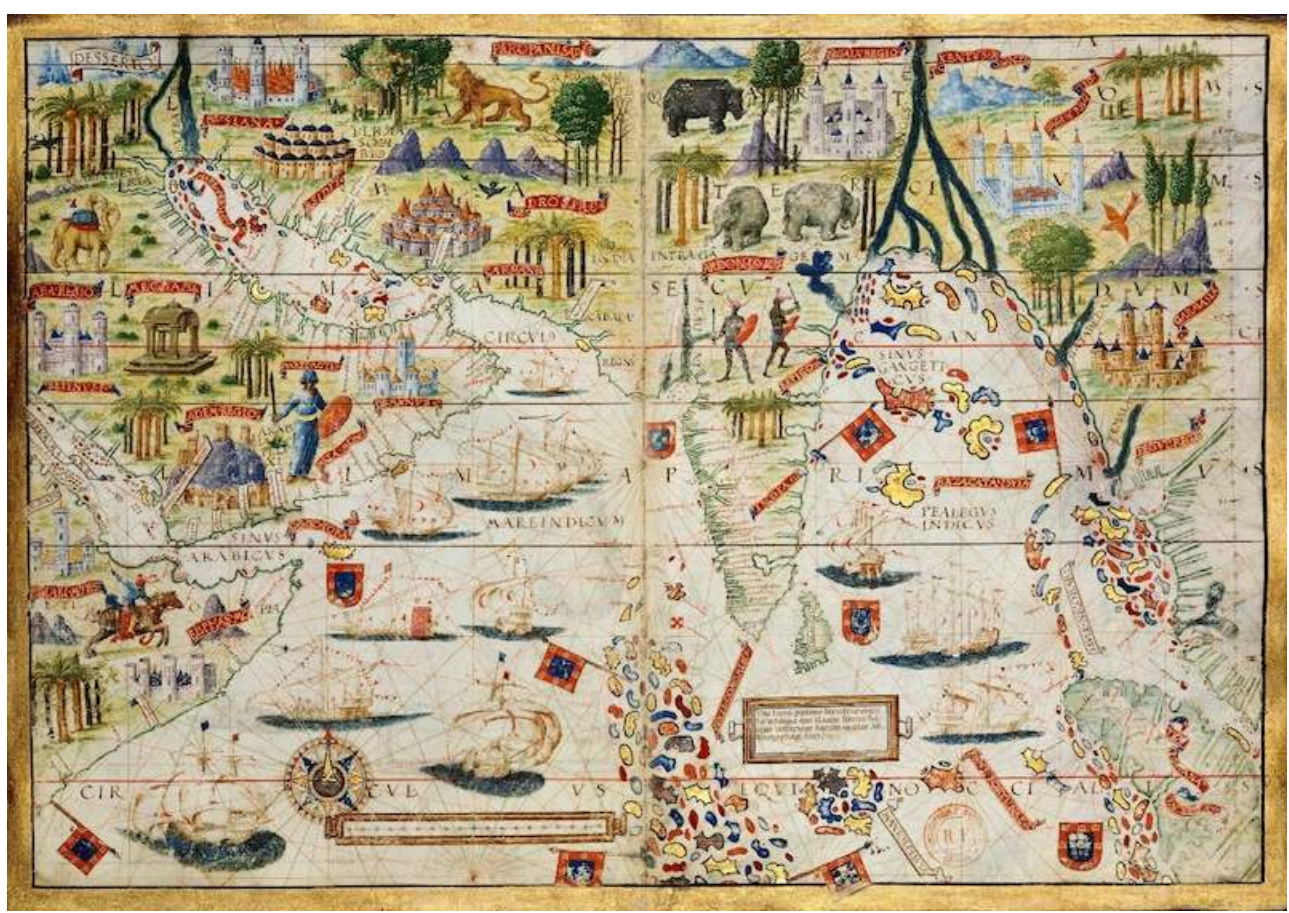

Dated c. 1519 from the Miller Atlas in La fabrique de I'Océan indien, Emmanuelle Vagnon and Eric Vallet eds., Paris: Editions de la Sorbonne, 2017, p. 113.

Source: https://www.mapmania.org/map/63688/1519_map_of_the_indian_ocean_and_surroundings

Students' analysis of such trade systems may also question the actors and the goods and commodities exchanged throughout the delineated units of analysis. In such a perspective, actors may include traders and customers but also intermediaries and diasporas, lesser-known minority groups such as the Peranakan Straits Chinese - a trade diaspora that established itself along the coasts of Malaysia and later on the island of Singapore, developing a unique hybrid Chinese-Malay culture that survives in the Baba Nyonya cuisine, still popular today in this part of the Indian Ocean.

41 Students may also ask themselves what types of goods and commodities travelled along the various networks (spices from India or the Moluccas, porcelain from China), and 
analyse the supply and demand for such goods, the means of transport used and the evolution of commercial, trading or navigation skills and techniques such as dhow ships, the use of monsoon winds, mapmaking, the development of banking and insurance, letters of credit, changes in supply and demand, and the evolution of political systems along the way such as empires, kingdoms, city-states and informal trade competitors such as pirates.

For thousands of years, connections made by water routes have helped integrate distant peoples through trade, contact and cultural influences. Water-based trade and travel have linked widely separated cultures since Antiquity. Therefore, water should be seen as a connecting element rather than as a barrier.

Although water-based trade routes have not received as much historical attention as land-based routes, they have been equally-if not more-important in the history of the world. Studying water-based trade routes allows historians to understand the complex interconnected network formed by the crossing of many maritime and land routes and to evaluate the significance of important crossroads that developed over time as core areas in a series of interconnected world systems which also included distant peripheries. One example of such water/land interface was the urban coastal network of Swahili city-states that developed along the East African coast from Somalia to Mozambique. The rise of the Swahili people was only made possible because they were able to profit from both land-based trade with Africa's interior and seaborne trade in the Indian Ocean.

As Michael Pearson recalls in his narrative of the history of the Indian Ocean from an oceanic perspective,

Our perceptions of the sea have changed dramatically over the last few decades. [...]

For most of us today the sea has little practical significance. This is very recent. [...]

In the past the sea was much more central in our minds, connecting people and

goods all over the world, inspiring great literature. (Pearson 2010: 1)

Why have seas and oceans regained such importance as units of analysis in the recent years?

In France, students in their final year in high school have to study a chapter in Geography entitled: "Globalization: Territories in a global context". The two examples chosen to illustrate the key ideas developed in the syllabus are the network of global cities and seas and oceans as global territories. The chapter recalls that, in the past decades, global trade has experienced a boom in international maritime transport activities. Nowadays, world freight amounts to $71 \%$ of global transports, with figures rising to $90 \%$ for intercontinental transports.

As oceans cover more than $71 \%$ of the world surface, maritime hubs, networks, sea routes, straits and passageways have gained considerable importance and global geopolitics has gained momentum with ever more important issues: international migrations, piracy, global transboundary pollution, the scramble for the Arctic and the control of the Antarctic sanctuary, global warming, overfishing and the threats to ocean sustainability, the emergence of India and China as major powers on the global stage and the shift of global power towards the Asian-Pacific region, and so on.

The development of interconnected ocean territories constitutes a major trend in globalization, along with the expanding garland of mostly coastal urban hubs called global cities. Due to their geographic location, most of these are interfaces between land and water-based trade networks. This reorientation of human activity towards 
coastal areas and seas and ocean basins have thus made the latter territories of globalization in their own right and created new communication networks, global power shifts, new areas of conflicting interests, and an updated international legislation. These territories are also highly vulnerable to environmental challenges as they attract and concentrate an ever-growing human population. Risk assessment policies are being implemented in order to prevent major threats caused by the challenges of global warming.

Very recently, a new reform in French lycées has included this topic in the syllabus for the Baccalauréat. In the new syllabus, a whole chapter is now devoted to seas and oceans as the heart of the global system. The latest reform also includes geopolitical studies encouraging teachers to take a closer look at maps with their students, and focusing on global environmental challenges. It also acknowledges the growing strategic importance of the Indian Ocean as a central area in the global system through various regional case studies on the Straits of Melaka or the Persian Gulf. Through various cartographic analyses at different scales (global, local), students understand that the Indian Ocean is to be regarded as a strategic territory torn between regional rivalries and international cooperation.

Map analysis has become a key component in the French syllabi in History and Geography. Teachers are encouraged to use more maps during classes and develop students' ability to read and analyse different types of maps as an important source of information on the world's past and on contemporary events. This encourages students to adopt a global perspective and understand that some contemporary issues and challenges affect multiple areas around the world and can only be addressed through multilateral cooperation. Through the study of maps, students understand that environmental issues such as global warming or transboundary pollution call for an international response and cut across former conceptions of space such as the national scale and the concept of territory.

The concept of territory is a rather new addition to the study of Geography in France. The notion of space which was previously used was thought to be too vague to describe areas under human control, whereas a territory can be bounded conceptually (as a space) or physically (as a territory). Space is an abstract vision, but in Geography in France, a territory can be defined as an area which is structured, organised, divided by human activity. Sometimes, space and territory coincide. The analysis of a territory is the analysis of man's interactions with and impacts on his environment.

51 In Introduction à la géohistoire, French scholar Christian Grataloup explains his concept of 'geohistory'. He forged this term to display the growing need for transdisciplinary approaches to understand the complexities of an ever-more connected world. Géohistoire associates the tools of the historian with those of the geographer to insist on the simultaneity of various events. Grataloup suggests that maps are important tools to develop a global perspective on the history of the world. Traditional historical narratives usually insist on the succession of events and the construction of parallel histories with no immediate connections between them. Maps, on the other hand, display a bird's eye view that may help our understanding of past and present connections between different parts of the world, particularly in the case of seas and oceans.

Seas and oceans have become such important territories for our understanding of global processes that entire research fields have now turned them into key categories 
through which to analyse the past, present and future developments of the global system. They have become historians and geographers' new units of analysis to understand and teach students the growing complexities of globalization.

\section{BIBLIOGRAPHY}

Beaujard, Philippe. Les Mondes de l'Océan Indien. 2 vols. Paris: Armand Colin, 2012.

Beaujard, Philippe. The Worlds of the Indian Ocean: A Global History. 2 vols. Cambridge UP, 2019.

Bentley, Jerry. "Seas and Ocean Basins as Frameworks of Historical Analysis." Geographical Review 89-2 (April 1999): 215-225. DOI: 10.2307/216087

Braudel, Fernand. “Personal Testimony.” Journal of Modern History 44.4 (December 1972): 448-467. https://www.jstor.org/stable/1876804

Braudel, Fernand. La Méditerranée et le monde méditerranéen à l'époque de Philippe II. Paris: Armand Colin, 1949.

Braudel, Fernand. The Mediterranean and the Mediterranean World in the Age of Philip II. 2 vols. London: Collins, 1972.

Broeze, Frank, ed. Brides of the Sea: Port Cities of Asia from the $16^{\text {th }}-20^{\text {th }}$ Centuries. Sydney: New South Wales UP, 1989.

Chaudhuri, Kirti Narayan. Trade and Civilization in the Indian Ocean: An Economic History from the Rise of Islam to 1750. Cambridge: Cambridge UP, 1985.

Crosby, A. W. The Columbian Exchange: Biological and Cultural Consequences of 1492. Westport: Greenwood Publishing Co., 1972.

Gilbert, Erik. "Introduction to the Indian Ocean World. Teaching about the Indian Ocean World." AP World History. Workshop material (2006-2007): 6-12. https://apcentral.collegeboard.org/pdf/ world-history-sf-indian-ocean-world07.pdf?course=ap-world-history

Gipouloux, François. La Méditerranée asiatique. Villes portuaires et réseaux marchands en Chine, au Japon et en Asie du Sud-Est, XVI ${ }^{e}-X X I^{e}$ siècle. Paris: CNRS éditions, 2009.

Goucher, Candice and Walton, Linda. World History. Journeys from Past to Present. Abington: Routledge, 2013.

Grataloup, Christian. Introduction à la géohistoire. Paris: Armand Colin, 2015.

Gunder Frank, Andre. ReOrient. Global Economy in the Asian Age. Berkeley: U. of California P., 1998.

Pearson, Michael. The Indian Ocean. New York: Routledge, 2010.

Wallerstein, Immanuel. The Modern World-System. 3 vols. New York: Academic Press, 1974. 


\section{ABSTRACTS}

The units of analysis historians and geographers use dictate what questions are asked, which stories are told and eventually which patterns emerge. Units of analysis are framing tools that help scholars identify global patterns. By focusing on seas and ocean basins, one can bring out the processes of interaction that link peoples living in the various regions around a sea and ocean basin. Nowadays, as Global History is emerging as a new historical paradigm and as a form of "global geography" is being taught in French high schools, the Indian Ocean framework, like the Mediterranean Sea decades ago with historians such as Fernand Braudel, is commonly used to explain the early development of global trade networks and regional cross-cultural interactions in what is commonly referred to as the "Old World", as opposed to the "New World" "discovered" by Christopher Columbus in 1492. This article deals with this recent and unprecedented use of the Indian Ocean as a global framework for historical and geographical analysis in teaching and research fields and explains why teaching about the Indian Ocean world as a zone of dynamic interaction between peoples makes more pedagogical, historical and geographical sense than teaching about it through traditionally delineated national or continental units in a globalized world. It also discusses the limitations of the use of such a broad unit of analysis and the potential consequences of a teleological bias that prompts historians and teachers to try integrating the human past into a comprehensive big picture that emphasises the shared experiences of all humans sometimes at the expense of a somewhat traditional historiography, focusing on the idea that the human past is marked by important differences between peoples across space and time. The conclusion assesses how global historians and geographers are attempting to reconcile the idea of an increasing integration at the global scale with that of proliferating difference at the local and regional scales and envisages the ways in which they can construct and teach a global historical and geographical narrative of the past and of our contemporary world that may help students understand the growing complexities and challenges of globalization, including global environmental issues such as the building of a sustainable future for all.

Les unités d'analyse que les historiens et les géographes utilisent déterminent quelles sont les questions posées, quelles histoires sont racontées et, en fin de compte, quels motifs récurrents en émergent. Les unités d'analyse sont des outils d'encadrement qui permettent aux chercheurs d'identifier les modèles mondiaux. Ainsi, en mettant l'accent sur les bassins maritimes et océaniques, on peut faire ressortir plus clairement les processus d'interaction qui relient les peuples vivant dans les différentes régions autour d'un bassin maritime et océanique. De nos jours, alors que l'histoire mondiale apparaît comme un nouveau paradigme historique, et qu'une forme de "géographie mondiale" est enseignée dans les lycées français, le cadre de l'océan Indien, comme la Méditerranée il y a plusieurs décennies à l'instar de Fernand Braudel, est couramment utilisé pour expliquer le développement précoce des réseaux commerciaux mondiaux et les interactions interculturelles régionales dans ce que l'on appelle communément le "Monde antique", par opposition au "Nouveau Monde" "découvert" par Christophe Colomb en 1492. Cet article traite de cette utilisation récente et sans précédent de l'océan Indien en tant que cadre mondial pour l'analyse historique et géographique dans les domaines de l'enseignement et de la recherche. Il expliquera pourquoi enseigner le monde de l'océan indien en tant que zone d'interaction dynamique entre les peuples a plus de sens pédagogiquement et historiquement parlant dans un monde globalisé que l'enseigner à travers les unités nationales ou continentales traditionnelles. Il examine également les limites de l'utilisation d'une telle unité d'analyse large et les conséquences potentielles d'un biais téléologique menant les historiens et les enseignants à essayer d'intégrer le passé humain dans un grand tableau complet qui met l'accent sur les expériences partagées de tous les êtres humains au détriment d'une historiographie quelque peu 
traditionnelle axée sur l'idée que le passé humain est marqué par des différences importantes entre les peuples, à travers l'espace et le temps. La conclusion évalue la façon dont les historiens et les géographes mondiaux tentent de concilier l'idée d'une intégration croissante à l'échelle mondiale avec celle de la prolifération des différences aux échelles locales et régionales et envisage la façon dont ils peuvent construire et enseigner un récit historique et géographique mondial du passé et de notre monde contemporain qui peut aider les élèves à comprendre les complexités et les défis croissants de la mondialisation, y compris les problèmes environnementaux mondiaux tels que la construction d'un avenir durable pour tous.

\section{INDEX}

Mots-clés: globalisation, histoire, géographie, unité d'analyse, enseignement, Braudel Fernand, Océan Indien

Keywords: globalization, history, geography, unit of analysis, teaching, Braudel Fernand, Indian Ocean

\section{AUTHOR}

\section{INGRID SANKEY}

Teacher of History, Geography and Globalization at ESPOL (European School of Political and Social Sciences) attached to UCL (Université Catholique de Lille). Ingrid Sankey holds a PhD in British civilization from the University of Lille 3. Her thesis (defended in 2008) dealt with the issue of Indirect Rule in the Indian Princely States in the heyday of the British Empire. She is currently teaching a course entitled "History, Geography and Globalization" at the ESPOL and history and geography for an international OIB (option internationale du baccalauréat) section at Thérèse d'Avila European High School in Lille. She has been a member of the SARI (Society for the promotion of Research and Activities on the Indian worlds) since 2008 and contributed to several SARI conferences and publications on India, Africa and Globalization. Her paper entitled "Les princes et le Raj britannique ou les aléas du système d'administration indirecte dans l'Empire des Indes" was published in Decolonization and the Struggle for National Liberation in India (1909-1971), edited by Thierry Di Costanzo and Guillaume Ducoeur, in Anglo-American Studies (vol. 48), Peter Lang Edition, 2014. Her main research topics focus on the analysis of cultural representations and intercultural issues, exoticism, colonial and post-colonial issues, industrial Britain, British society in the $19^{\text {th }}$ century, Global history and geography and Globalization. Contact: iclairesankey2003[at]yahoo.fr 